\title{
Adhesion of enteroaggregative Escherichia coli to formalin-fixed intestinal and ureteric epithelia from children
}

\author{
SUSAN HICKS, D. C. A. CANDY and A. D. PHILLIPS* \\ Department of Child Health, King's College School of Medicine and Dentistry, London SE5 8RX \\ and ${ }^{*}$ Academic Department of Paediatric Gastroenterology, Queen Elizabeth Hospital for Children, \\ London E2 8PS
}

\begin{abstract}
The adhesion characteristics of enteroaggregative Escherichia coli (EAggEC) to the mucosal surfaces of formalin-fixed paediatric intestinal and ureteral tissue were studied. The technique offers a means of overcoming the problem of limited tissue access in childhood and a way of examining the initial steps of bacterial adhesion. Five EAggEC strains isolated from children with diarrhoea in the UK and a well characterised, prototype EAggEC strain (221) were examined. Five of the six EAggEC strains showed preferential adhesion to jejunal mucosa with limited adhesion to ileum and colon. Five of the six also adhered to ureteric tissue. EAggEC can adhere to proximal, as well as distal, regions of the gastrointestinal tract in children, a previously unrecognised characteristic.
\end{abstract}

\section{Introduction}

Enteroaggregative Escherichia coli (EAggEC) is a recently described category of $E$. coli that adheres to HEp-2 cells in an aggregative or 'stacked-brick' pattern [1]. This pattern is distinct from localised and diffuse patterns of adhesion which are also detected in the HEp-2 cell assay; localised adhesion is characteristic of enteropathogenic E. coli [2] cells which attach to, and efface, the brush border of the intestine [3], whereas the role of diffuse adhering $E$. coli in diarrhoea is unclear $[1,4,5]$.

EAggEC strains have been implicated epidemiologically in acute and chronic diarrhoea in children from developing countries [6-8] and more recently in the UK [9]. Ethical considerations prohibit the use of large quantities of ex-vivo tissue from children and investigations into the pathogenesis of EAggECassociated diarrhoea have included the use of animal models [10,11], isolated enterocytes [12], brief

Received 12 July 1995; accepted 2 Oct. 1995.

* Present address and address for correspondence: Dr A. D. Phillips, University Department of Paediatric Gastroenterology, Royal Free Hospital, Pond Street, London NW3 2QG. incubations with ex-vivo human tissue [13], and invitro organ culture [14]. The use of formalin-fixed surgical specimens offers a means of overcoming limited tissue access and has been used to study bacterial adhesion in man $[13,15]$. The one EAggEC strain studied previously [13] showed preferential adhesion to colonic mucosa. Generally, it is considered that EAggEC strains bind preferentially to the distal rather than the proximal bowel $[13,14]$, although Raj et al. have demonstrated adhesion to isolated duodenal enterocytes from adults [12].

The use of formalin-fixed tissue is practicable because, although fixation is achieved by the crosslinking of neighbouring protein groups, surface carbohydrate receptors remain intact [16]. Furthermore, the use of this fixed material, which otherwise would be destroyed after definitive histological examination, enables studies on many regions of the gastrointestinal tract and other mucosal surfaces.

The ability of EAggEC to adhere to ureteral mucosa was also examined because of the association of diarrhoea with urinary tract infection (UTI) [17], and because some $E$. coli of colonic origin share phenotypic characteristics with those that cause UTI [18]. E. coli of UTI origin have been shown to adhere to human ureteral cells in vitro [19]. However, only 
one strain (TL100) of EAggEC of intestinal origin has been examined with fresh and formalin-fixed adult ureteral tissue [13] - strong adhesion to fixed ureteral tissue was found.

The aim of this work was to examine the adhesion characteristics of EAggEC strains in studies with formalin-fixed surgical tissue from paediatric patients.

\section{Materials and methods}

\section{Bacterial strains}

Five enteroaggregative $E$. coli strains (3862 [O85:H1], WJ19/10 [O126:H27], AN11/13 [O55:H4], HR15/6 [O126:H27] and LC9/6 [O111ab:H21]) that had been isolated from children with acute and chronic diarrhoea at Queen Elizabeth Hospital for Children (QEHC) were examined. The strains had been detected by their aggregative pattern in the HEp-2 cell assay and were aggregative adherence (AA) gene probe positive [9]. The sensitive and specific gene probe used was that described by Baudry et al. [20] which recognises a $1-\mathrm{kb}$ region on the $60-\mathrm{MDa}$ plasmid present in EAggEC. Strain 221, another well characterised EAggEC isolate from an American student who had returned from Mexico with travellers' diarrhoea [21], was also examined. This strain was used subsequently to challenge adult volunteers and was found to cause diarrhoea [22]. An enteropathogenic strain of $E$. coli (EPEC KH1/8) O114:H2, also isolated at QEHC, was used as a positive control. This strain showed an attaching-effacing lesion in vivo in a biopsy of the proximal small intestine of a patient with chronic diarrhoea (A. D. Phillips, unpublished observation) and caused an attaching-effacing lesion in vitro in human small intestinal organ culture ( $\mathrm{S}$. Knutton, personal communication). In the HEp-2 cell assay, EPEC KH1/8 showed a localised pattern of adhesion [23]. A normal flora E. coli strain (SC13; kindly provided by $\operatorname{Dr} S$. Knutton, University of Birmingham) which did not adhere to HEp-2 cells in culture was used as a negative control as was laboratory E. coli strain HB101.

All bacterial strains were streaked on to MacConkey agar. Five pure colonies were removed after overnight incubation and stored at $-70^{\circ} \mathrm{C}$ in Microbank cryovials (Pro-Lab Diagnostics) as the stock bacteria for adhesion assays. Before incubation with fixed tissue, all EAggEC strains were examined in a HEp-2 assay to ensure that the aggregative phenotype had been maintained during storage.

\section{Tissue samples}

Macroscopically normal, formalin-fixed, surgical tissue available after histological examination was used for the adhesion experiments.
Four jejunal specimens (from patients aged 12 days, 9, 36 and 135 months), five ileal specimens (from patients aged 12 days, 10, 13, 51 and 65 months) and five colonic specimens (from patients aged 6 days, 4, 24, 53 and 138 months) were used. Ureteral specimens from four children (aged $12,19,49$ and 65 months) were examined; tissue from children under 12 months of age was not available.

\section{Adhesion assay}

The adhesion assay was performed as described by Yamamoto et al. [13]. Bacterial strains were incubated aerobically in brain heart infusion (BHI) broth for $18 \mathrm{~h}$ at $37^{\circ} \mathrm{C}$ without shaking. Formalin-fixed tissue was cut into $3-\mathrm{mm}^{2}$ pieces and washed twice in $100 \mathrm{ml}$ of Krebs-Ringer buffer for $3 \mathrm{~h}$ at room temperature to remove residual fixative. Preliminary experiments showed that any trace of fixative remaining after washing did not affect $E$. coli viability. The tissue was then added to a mixture of $1 \mathrm{ml}$ of bacterial culture in BHI (c. $10^{8} \mathrm{cfu}$ as measured by serial dilution and plating on to MacConkey agar) and $1 \mathrm{ml}$ of sterile phosphate-buffered saline (PBS) containing D-mannose $0.5 \% \mathrm{w} / \mathrm{v}$ and incubated statically for $45 \mathrm{~min}$ at $37^{\circ} \mathrm{C}$.

After incubation, the tissue was washed three times with sterile PBS to remove non-adhering bacteria, fixed in phosphate-buffered glutaraldehyde $3 \%$ and post-fixed with aqueous osmium tetroxide $1 \%$. After washing with distilled water, the tissue was dehydrated through a graded series of ethanol before critical point drying with liquid $\mathrm{CO}_{2}$. The samples were sputtercoated with gold-palladium and coded before being examined in a JEOL JSM-5300 scanning electron microscope (SEM) so that the operator was unaware of the identity of the sample. Ten random fields were examined from each specimen at a magnification of 3500 and the number of coliform bacteria adhering to the mucosa in each SEM field was recorded. Results from each of the specimens were pooled according to mucosal region and experimental $E$. coli strain, to give bacterial counts from a total of 40 fields of view for jejunal and ureteral tissue, and 50 fields for ileal and colonic mucosae. Counts from control and experimental samples were compared by non-parametric analysis by the MannWhitney test, with a $p$ value of $<0.05$ recorded as significant.

Pieces of jejunum, ileum, colon and ureter with PBS alone were used to establish the normal range $(95 \%$ confidence limits) for the presence of bacteria without the addition of the experimental strains. For these experiments, the numbers of coliform bacteria from 40 SEM fields per mucosal specimen, at the same magnification, were counted. 


\section{Results}

\section{Controls}

The median number of bacteria adhering to jejunum gave $95 \%$ confidence limits of $0-3$ bacteria/SEM field. This value was $0-2$ for ileal and $0-1$ for colonic tissue. Generally, fewer bacteria were found adhering to ureteric specimens and the median value gave $95 \%$ confidence limits of $0-0.5$ bacteria/field.

\section{Adhesion to jejunum}

Five of six EAggEC strains adhered significantly to paediatric jejunal tissue (Table 1 and Fig. 1a). Strains 3862, HR15/6, LC9/6 and WJ19/10 all demonstrated highly significant adhesion to jejunum $(\mathrm{p}<0.001)$. Strain AN11/13 adhered in lower, but still significant $(p<0.04)$, numbers than the previous strains. All strains demonstrated evidence of aggregative adherence to the mucosal surface (Fig. 2b). The median number of adhering bacteria varied from strain to strain and between specimens. However, strain 3862 adhered to jejunum in significantly greater numbers
Table 1. Adhesion of E. coli to formalin-fixed mucosae

\begin{tabular}{|c|c|c|c|c|}
\hline \multirow{2}{*}{$\begin{array}{l}\text { E. coli } \\
\text { strains }\end{array}$} & \multicolumn{4}{|c|}{ Adhesion to mucosal tissue from } \\
\hline & Jejunum & Ileum & Colon & Ureter \\
\hline \multicolumn{5}{|l|}{ EAggEC } \\
\hline 3862 & + & + & + & + \\
\hline HR15/6 & + & + & - & + \\
\hline $\mathrm{LC} 9 / 6$ & + & + & - & + \\
\hline WJ19/10 & + & + & + & + \\
\hline AN11/13 & + & + & + & + \\
\hline 221 & - & - & + & - \\
\hline \multicolumn{5}{|l|}{ EPEC } \\
\hline $\mathrm{KH} 1 / 8$ & + & + & + & + \\
\hline \multicolumn{5}{|l|}{ Normal flora } \\
\hline $\mathrm{SC} 13$ & - & - & + & + \\
\hline HB101 & - & - & - & - \\
\hline
\end{tabular}

+ , represents significant adhesion $(\mathrm{p}<0.05)$;

- , represents insignificant adhesion $(p>0.05)$.

than any other strain $(p<0.05)$. An example of strain 3862 adhering to jejunal mucosa in comparison to control tissue is shown in Fig. 2a and 2b. EPEC strain $\mathrm{KH} 1 / 8$ (positive control) showed significant adhesion $(\mathrm{p}<0.02)$. Neither of the negative control E. coli
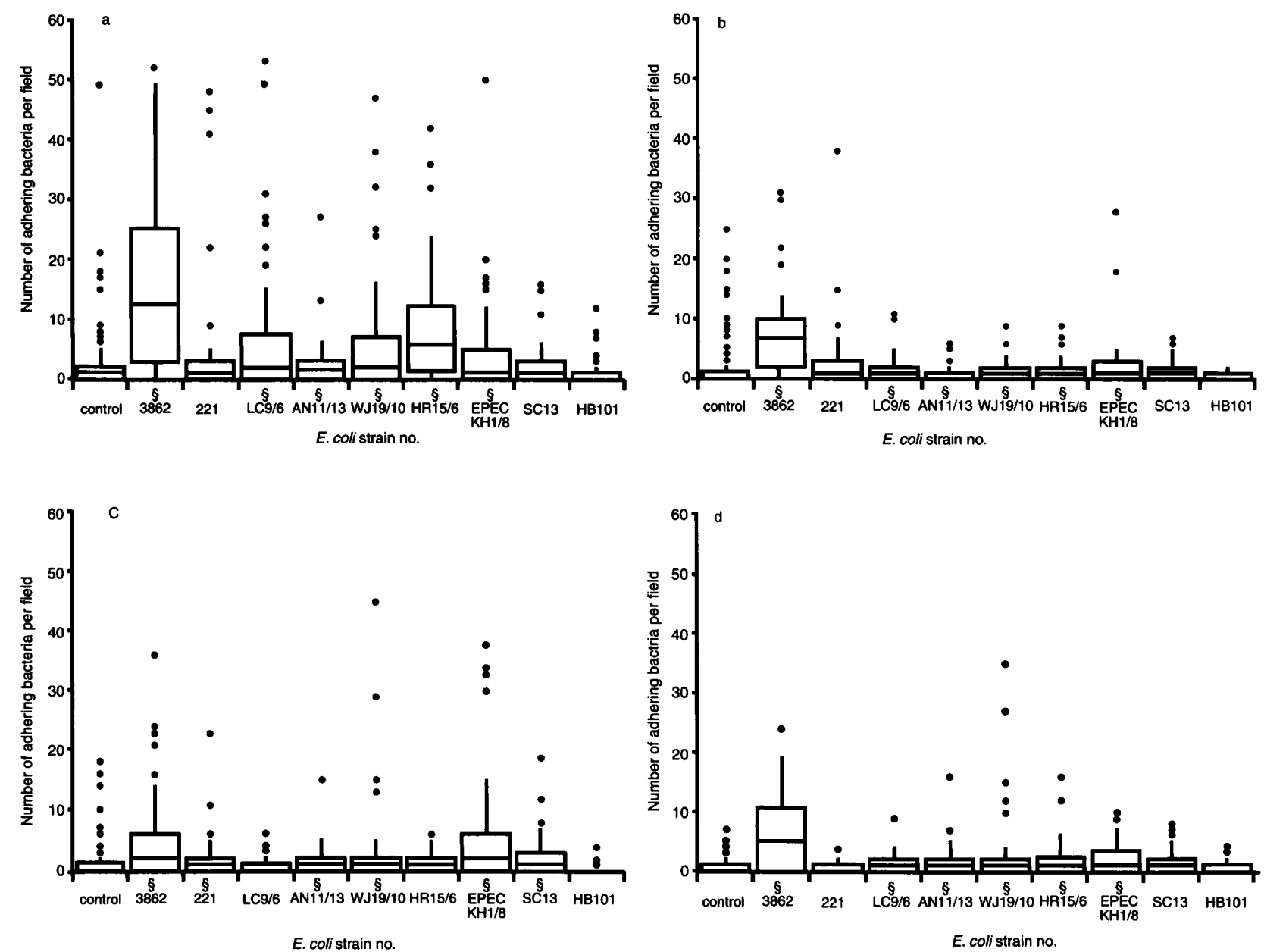

Fig. 1. Box and whisker plots showing the level of $E$. coli adhesion to fixed jejunal (a), ileal (b), colonic (c) and ureteral (d) mucosae. The boxes represent upper and lower quartiles about the median. The vertical lines represent the range unless outliers are present (represented as dots), in which case the lines represent one and a half times the interquartile distance. Total numbers of fields studied were: (a) control 160, E. coli strains 40, except HB101 30; (b) control 200, E. coli strains 50, except HB101 30; (c) control 200, E. coli strains 50 except HB101 30; (d) control 160, E. coli strains $40 . \S, \mathrm{p} \leq 0.05$ 
strains $\mathrm{SC} 13$ and $\mathrm{HB} 101$ showed significant adhesion $(p=0.71$ and $p=0.11$, respectively) to any of the four jejunal specimens.

\section{Adhesion to ileum}

Five specimens from this gut region were examined. Five of six EAggEC showed significant adhesion $(p<0.03)$ (Fig. 1b). Although fewer bacteria were found adhering to the ileum than to the jejunum, in all cases, strain 3862 again showed significantly greater adhesion than any other strain $(p<0.001)$ (Fig. 2d). As with jejunum, EPEC KH1/8 showed highly significant adhesion $(p<0.001)$ to ileum but neither of the negative control strains SC13 nor HB101 showed significant adhesion to it $(p=0.15$ and $p=0.13$, respectively).

\section{Adhesion to colon}

As with ileal mucosa, fewer bacteria were found adhering to the five colonic specimens than to jejunal tissue (Fig. 1c). Four of the six EAggEC strains showed significant adhesion to colonic mucosa -221 ( $p<0.03), 3862$, AN11/13 and WJ19/10 ( $<<0.001)$. Both the EPEC and normal flora control $E$. coli strains also showed significant adhesion $(\mathrm{p}<0.001)$ but the negative control strain HB101 did not $(p=0.06)$.

\section{Adhesion to ureter}

Five of six EAggEC showed significant adhesion $(p<0.0001)$ to ureteral epithelial cells (Fig. 1d). Strain 221 did not show significant adhesion $(p=0.28)$. Bacteria adhered in a more diffuse manner than to gut mucosae with the bacterial cells appearing as scattered individuals rather than in small groups (Fig. 2h). Both the EPEC and normal flora E. coli strains showed significant adhesion $(p<0.001)$. Strain HB101 did not adhere in significant numbers $(\mathrm{p}=0.98)$.

No correlation was found between the degree of bacterial adhesion and the age of the child providing the sample.

\section{Discussion}

The results demonstrate that each of the six EAggEC strains showed significant adhesion to formalin-fixed cells of the intestinal samples from children although there were regional differences. The use of formalinfixed tissue to examine EAggEC adhesion to the intestine was first reported by Yamamoto and colleagues $[13,15]$. Similar results were found between unfixed and fixed tissue and the technique was applied to other bacterial pathogens, including Vibrio cholerae [24] and enterotoxigenic E. coli [25].
However, only one strain of EAggEC was examined and the tissue samples used came from a narrow age range of children [13]. The present study included more strains of EAggEC, and this may, in part, explain the variable pattern of the results. Yamamoto et al. [13] make no mention of finding bacteria adhering to the mucosal surface of control specimens and, therefore, any adhesion by the EAggEC strain was considered significant. However, a low level of bacterial adhesion was found in controls in the present study. Evans et al. [26] showed that viable bacteria could be isolated from jejunal mucosal homogenates from children without diarrhoea, suggesting that, in man, bacteria may be present in vivo at the mucosal surface without disease. This could account for the presence of bacteria found on control specimens.

Another reason for variation in results may be the requirement, in this study, that definitive histological examination be complete before the release of the tissue. Therefore, tissue remained in phosphatebuffered formaldehyde $4 \%$ for up to 90 days before use. It is possible that such a lengthy fixation, with exposure to the atmosphere on several occasions, could have altered the binding capacity of the tissue and could account for the adhesion to colonic mucosa observed with the negative control. Yamamoto et al. [13] used tissue after an unspecified period of fixation. However, because adhesion under these experimental conditions involves carbohydrate receptors, which are unaffected by formaldehyde, we discount this as an important factor.

Data presented here indicate that adhesion to jejunal mucosa may be a particularly important virulence factor of EAggEC. In the normal fasting state, the proximal small intestine is not sterile and contains $10^{3}-10^{4}$ bacteria/ml of luminal fluid [27], yet this normal flora does not cause diarrhoea. The ability to adhere in vivo to jejunal mucosa in significantly large numbers with or without the expression of other known virulence factors, such as haemolysin-like toxins [28] or enterotoxins, could lead to the diarrhoea associated with EAggEC.

Previous reports of the distribution of EAggEC adhesion to intestinal mucosae are at variance with the results presented here. Knutton et al. found that EAggEC strains (including some isolated from children with diarrhoea from QEHC) adhered preferentially to adult colonic mucosa in organ culture [14] and one isolate examined with fixed intestinal tissue from children was found to adhere to ileal mucosa [13]. These reports suggest that EAggEC strains colonise distal ileum or colon. However, in the present experiments with fixed tissues of a wide range of specimens of jejunum, ileum and colon from paediatric age groups, EAggEC strains adhered to them all but particularly to jejunal mucosa. 
$\mathbf{a}$

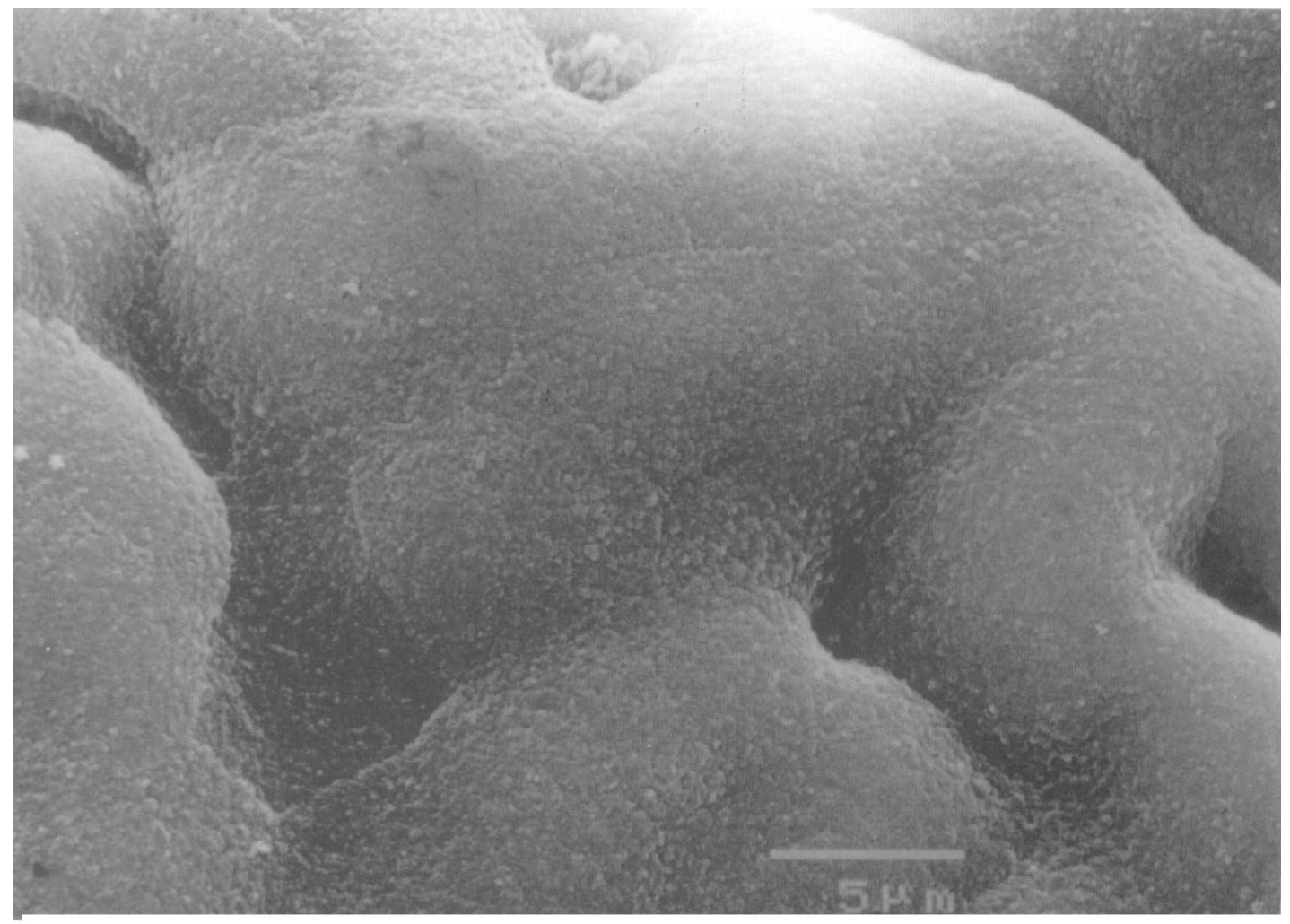

$\mathbf{b}$

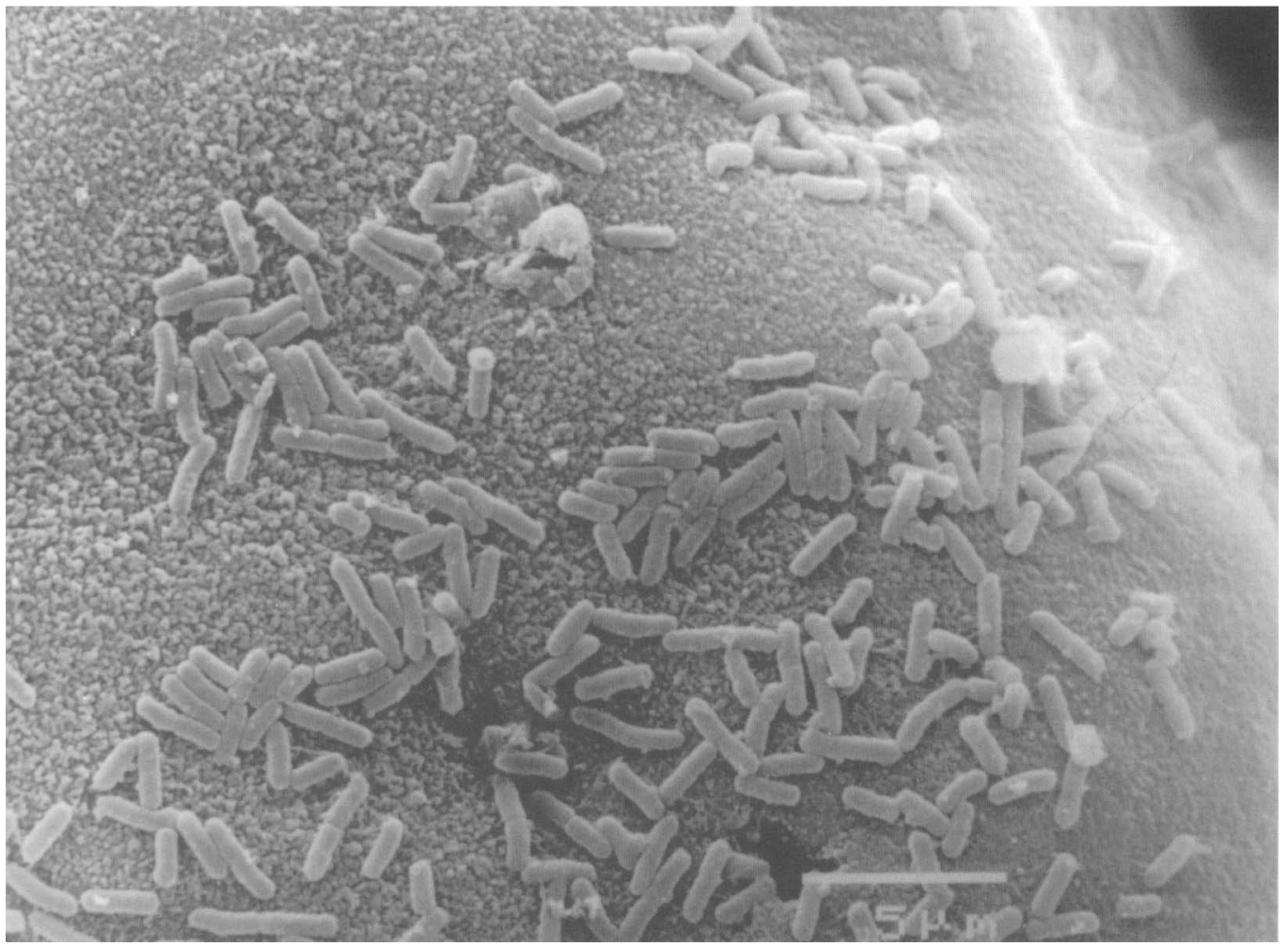

Fig. 2. Scanning electronmicrographs showing enteroaggregative $E$. coli strain 3862 adhering to formalin-fixed mucosae: a, jejunum control; b, jejunum with EAggEC strain 3862 (note the aggregative groups of bacteria); c, ileum control; d, ileum with EAggEC 3862; e, colon control; f, colon with EAggEC strain 3862; $\mathbf{g}$, ureter control; h, ureter with EAggEC 3862. 
c

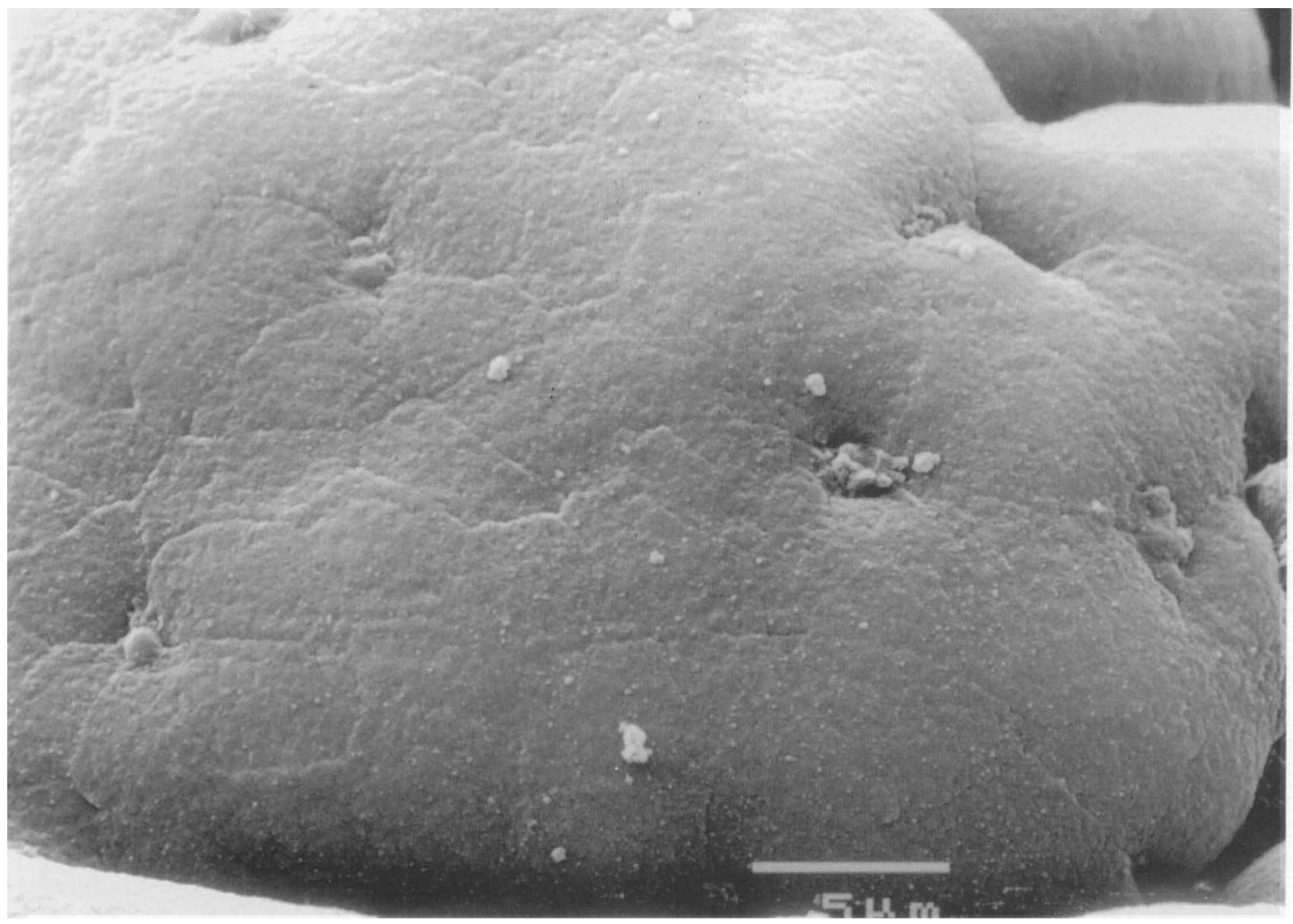

d

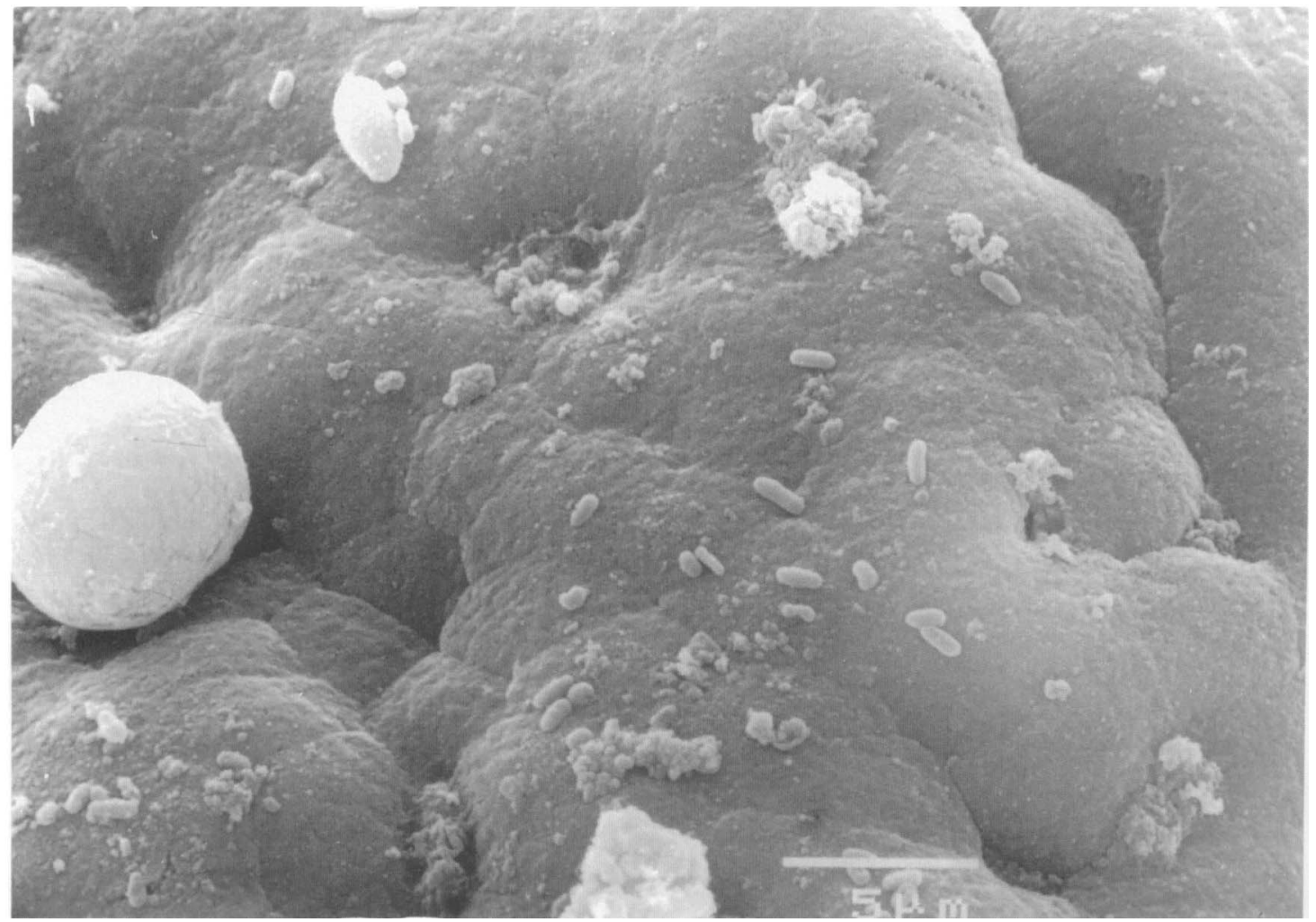


$\mathbf{e}$

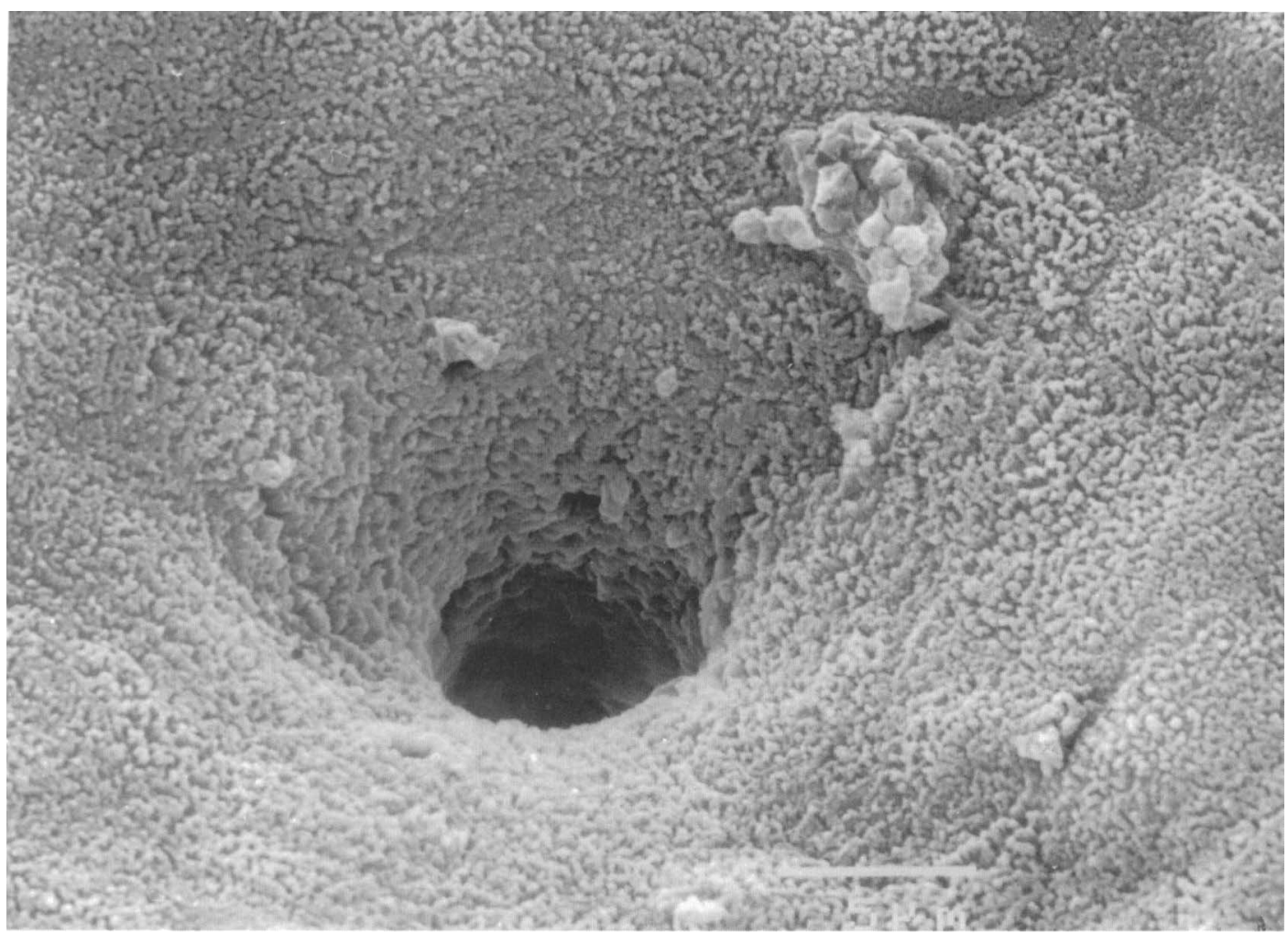

$\mathbf{f}$

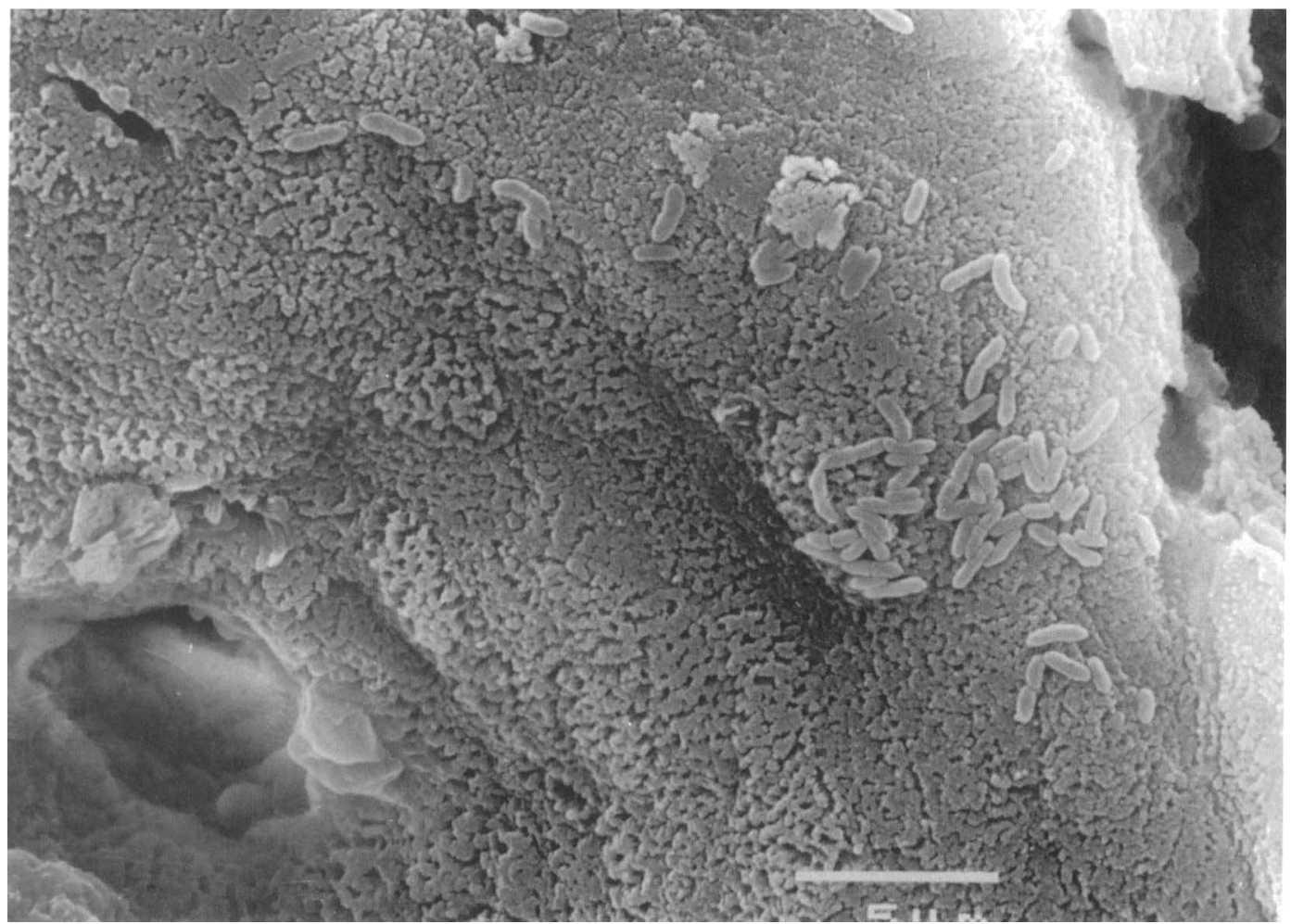

Fig. 2. Scanning electronmicrographs showing enteroaggregative $E$. coli strain 3862 adhering to formalin-fixed mucosae: a, jejunum control; b, jejunum with EAggEC strain 3862 (note the aggregative groups of bacteria); c, ileum control; d, ileum with EAggEC 3862; e, colon control; f, colon with EAggEc strain 3862; g, ureter control; h, ureter with EAggEC 3862. 
g

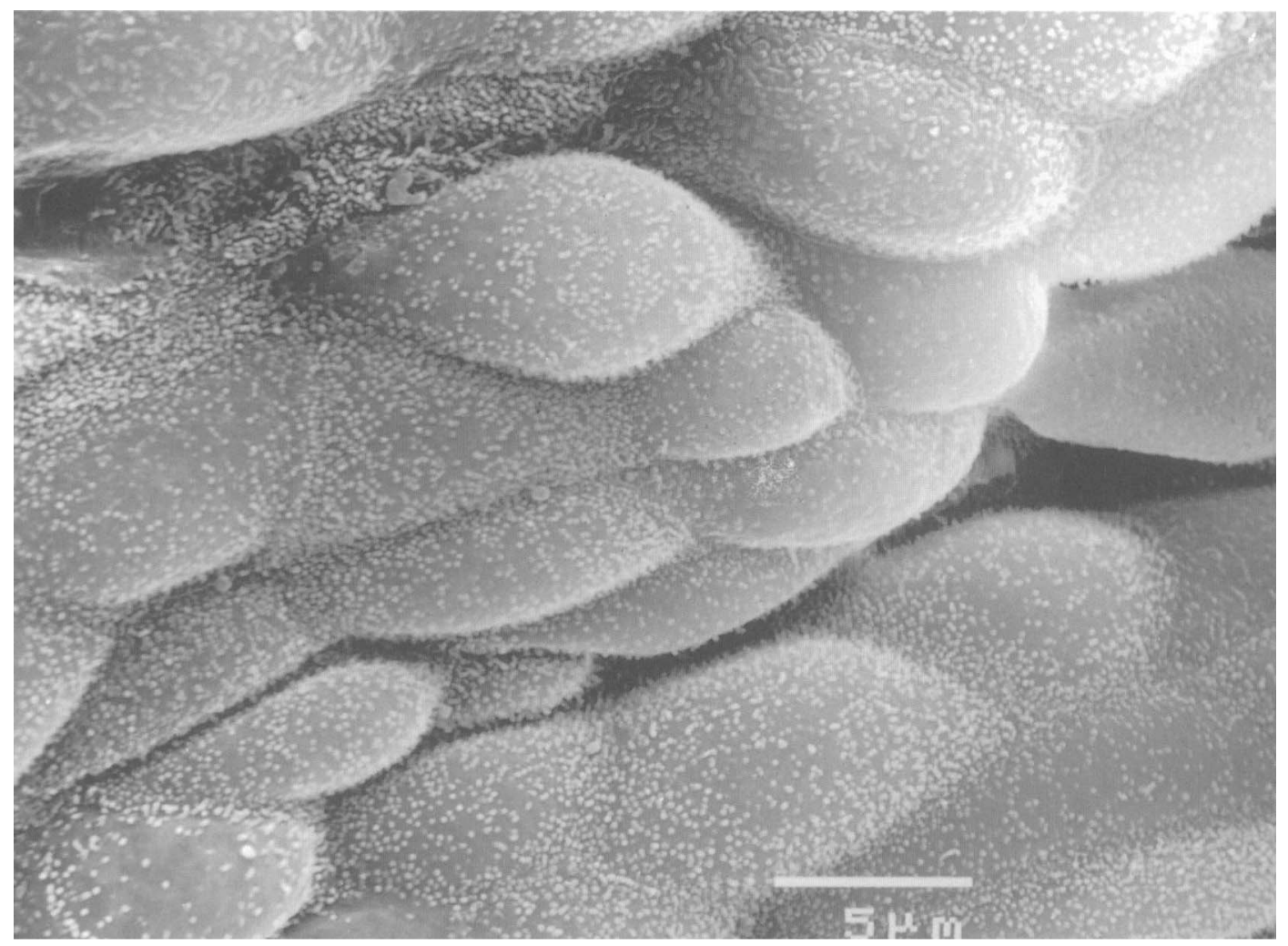

h

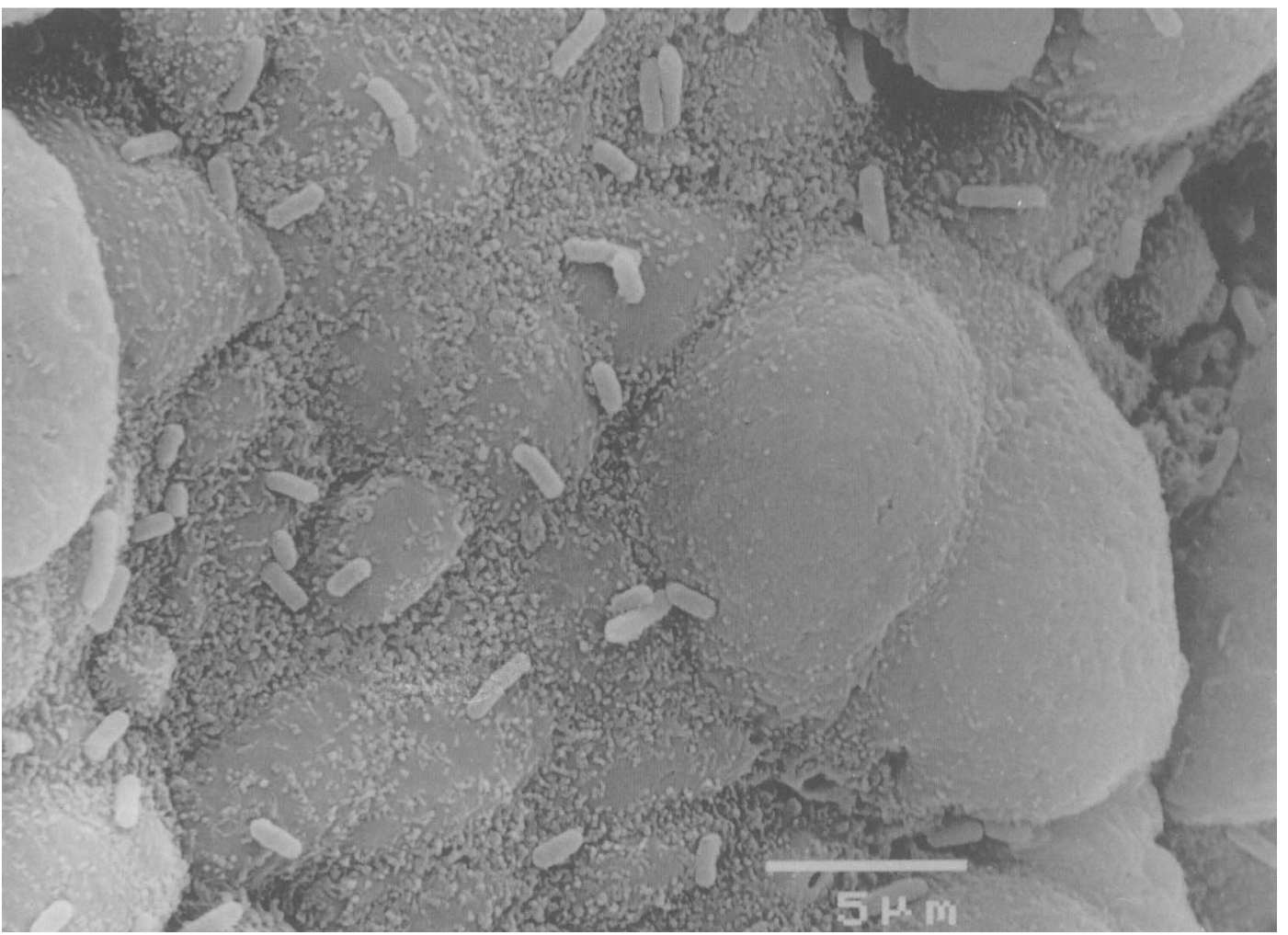


The finding of Raj et al. [12] that $35 \%$ of EAggEC strains adhered to isolated duodenal enterocytes from adults agrees with our observations that adhesion to the proximal small intestine is an important characteristic of this group of bacteria. Adhesion to jejunal mucosa in vivo could have a significant adverse effect on the absorptive and secretory capacity of the tissue, i.e., on the major functions of this gut region.

Most of the EAggEC strains also adhered to the epithelium of the ureter. This suggests that the urinary tract also expresses receptors for gastrointestinal pathogens that survive formalin fixation. This observation deserves further investigation with more $E$. coli strains, both experimental and control, of gastrointestinal origin. In light of evidence suggesting that $E$. coli strains of urinary origin can adhere to human ureteral cells in vitro [19], it would be of interest to examine this adhesive characteristic in EAggEC with a view to a possible role of ureteral colonisation leading to urinary tract infection.

The normal flora $E$. coli strain $\mathrm{SC13}$ adhered significantly to colonic and ureteric tissue. This is a surprising result and the ability of normal flora bacteria to adhere to intestinal mucosae should be studied further.

Heterogeneity appears to be an important feature of the EAggEC group, demonstrated here by the variation between strains in adhesion to fixed tissue. Unlike EPEC, in which certain serogroups are described as 'classic', many serogroups have been associated with EAggEC [6]. Five different serogroups were present in the six strains examined. Another feature of some EAggEC strains is that their DNA hybridises with a DNA probe for the gene region encoding the EAST1 toxin. Although this characteristic is thought to be common amongst EAggEC [29], of the six strains studied here only two gave positive results with the probe.

Several animal models have been proposed to demonstrate the putative lesion caused by EAggEC strains [10] and the diarrhoea that they induce [11]. Again there appears to be disagreement. Vial et al. [10], infected rabbit and rat ileal loops with EAggEC strains and found marked histological changes, including villus shortening and necrosis of villus tips. However, in the gnotobiotic piglet whole-animal model [11] only minor changes were found, such as oedema of villi and hyperaemia. Histological changes could not be examined in the work presented in this paper as the use of fixed tissue allowed only the initial stages of bacterial adhesion to be studied. Invitro organ culture of paediatric intestinal tissue is now being used to address some of these problems, and to further evaluate proximal intestinal adhesion of EAggEC.
In summary, the use of formalin-fixed tissue is an effective technique for studying the initial stages of bacterial adhesion in the paediatric age group and makes use of an untapped source of material that would otherwise be destroyed. By means of this technique, strains of a recently described group of bacteria, EAggEC, have been shown to adhere to jejunal mucosa, suggesting that EAggEC may be important pathogens of the proximal intestine in childhood.

We thank Dr S. Knutton for supplying the normal flora $E$. coli strain $\mathrm{SC} 13$ and the Histopathology Department, Great Ormond Street Hospital, London and Mr D. Drake for supplying the mucosal specimens. This work was funded by the King's College Hospital Joint Research Council, grant number JRC 159.

\section{References}

1. Nataro JP, Kaper JB, Robins-Browne R, Prado V, Vial P, Levine MM. Patterns of adherence of diarrheagenic Escherichia coli to HEp-2 cells. Pediatr Infect Dis J 1987; 6: 829-831.

2. Levine MM. Escherichia coli that cause diarrhea: enterotoxigenic, enteropathogenic, enteroinvasive, enterohemorrhagic, and enteroadherent. J Infect Dis 1987; 155: 377-389.

3. Ulshen MH, Rollo JL. Pathogenesis of Escherichia coli gastroenteritis in man - another mechanism. N Engl J Med 1980; 302: 99-101.

4. Cravioto A, Tello A, Navarro A et al. Association of Escherichia coli HEp-2 adherence patterns with type and duration of diarrhoea. Lancet 1991; 337: 262-264.

5. Girón JA, Jones T, Millán-Velasco F et al. Diffuse-adhering Escherichia coli (DAEC) as a putative cause of diarrhea in Mayan children in Mexico. J Infect Dis 1991; 163: 507-513.

6. Bhan MK, Raj P, Levine MM et al. Enteroaggregative Escherichia coli associated with persistent diarrhea in a cohort of rural children in India. J Infect Dis 1989; 159: 1061-1064.

7. Haider K, Faruque SM, Shahid NS et al. Enteroaggregative $E$. coli infections in Bangladeshi children: clinical and microbiological features. $J$ Diarrhoeal Dis Res 1991; 9: 318-322.

8. Wanke CA, Schorling JB, Barrett LJ, Desouza MA, Guerrant RL. Potential role of adherence traits of Escherichia coli in persistent diarrhoea in an urban Brazilian slum. Pediatr Infect Dis $J$ 1991; 10: 746-751.

9. Chan KN, Phillips AD, Knutton S, Smith HR, Walker-Smith JA Enteroaggregative Escherichia coli: another cause of acute and chronic diarrhoea in England? $J$ Paediatr Gastroenterol Nutr 1994; 18: 87-91.

10. Vial PA, Robins-Browne $\mathrm{R}$, Lior $\mathrm{H}$ et al. Characterization of enteroadherent-aggregative Escherichia coli, a putative agent of diarrheal disease. $J$ Infect Dis 1988; 158: 70-79.

11. Tzipori S, Montanaro J, Robins-Browne RM, Vial P, Gibson R, Levine MM. Studies with enteroaggregative Escherichia coli in the gnotobiotic piglet gastroenteritis model. Infect Immun 1992; 60: 5302-5306.

12. Raj P, Bhan MK, Srivastva R, Kumar R, Bhandari N, Arora NK Human enterocyte adhesion of enteroadherent Escherichia coli. Indian J Med Res 1990; 91: 368-371.

13. Yamamoto T, Endo S, Yokota T, Echeverria P. Characteristics of adherence of enteroaggregative Escherichia coli to human and animal mucosa. Infect Immun 1991; 59: 3722-3739.

14. Knutton S, Shaw RK, Bhan MK et al. Ability of enteroaggregative Escherichia coli strains to adhere in vitro to human intestinal mucosa. Infect Immun 1992; 60: 2083-2091.

15. Yamamoto $\mathrm{T}$, Koyama $\mathrm{Y}$, Matsumoto $\mathrm{M}$ et al. Localized, aggregative, and diffuse adherence to HeLa cells, plastic, and human small intestines by Escherichia coli isolated from patients with diarrhea. J Infect Dis 1992; 166: 1295-1310.

16. Allison RT. The effects of various fixatives on subsequent lectin binding to tissue sections. Histochem $J$ 1987; 19: 65-74.

17. Lima NL, Guerrant RL, Kaiser DL, Germanson T, Farr BM. A 
retrospective cohort study of nosocomial diarrhea as a risk factor for nosocomial infection. $J$ Infect Dis 1990; 161: 948952.

18. Wold AE, Caugant DA, Lidin-Janson G, de Man P, Svanborg C. Resident colonic Escherichia coli strains frequently display uropathogenic characteristics. $J$ Infect Dis 1992; 165: 46-52.

19. Elgavish A. Effects of Escherichia coli and E. coli lipopolysaccharides on the function of human ureteral epithelial cells cultured in serum-free medium. Infect Immun 1993; 61: 3304 3312.

20. Baudry B, Savarino SJ, Vial P, Kaper JB, Levine MM. A sensitive and specific DNA probe to identify enteroaggregative Escherichia coli, a recently discovered diartheal pathogen. $J$ Infect Dis 1990; 161: 1249-1251.

21. Mathewson JJ, Johnson PC, Dupont HL et al. A newly recognized cause of travelers' diarrhoea: enteroadherent Escherichia coli. J Infect Dis 1985; 151: 471-475.

22. Mathewson JJ, Johnson PC, DuPont HL, Satterwhite TK, Winsor DK. Pathogenicity of enteroadherent Escherichia coli in adult volunteers. J Infect Dis 1986; 154: 524-527.

23. Knutton S, Phillips AD, Smith HR et al. Screening for enteropathogenic Escherichia coli in infants with diarrhea by the fluorescent-actin staining test. Infect Immun 1991; 59: 365371.
24. Yamamoto T, Yokota T. Vibrio cholerae non-O1: production of cell-associated hemagglutinins and in vitro adherence to mucous coat and epithelial surfaces of the villi and lymphoid follicles of human small intestines treated with formalin. J Clin Microbiol 1988; 26: 2018-2024.

25. Yamamoto T, Fujita K, Yokota T. Adherence characteristics to human small intestinal mucosa of Escherichia coli isolated from patients with diarrhea or urinary tract infections. $J$ Infect Dis 1990; 162: 896-908.

26. Evans N, Brueton MJ, Turner PJ, McNeish AS. Bacterial culture of jejunal mucosa in childhood coeliac disease. Lancet 1975; 2: 35-36.

27. Gracey M. Intestinal microflora. In: Anderson CM, Burke V, Gracey M (eds) Paediatric gastroenterology. Melbourne, Blackwell Scientific, 2nd edn. 1987: 239-247.

28. Knutton S, Shaw RK, McNeish AS, Baldwin TJ, Williams PH, Bhan MK. Calcium, enteropathogenic $E$. coli, enteroaggregative E. coli and persistent diarrhoea. In: McNeish AS, Mittal SK, Walker-Smith JA (eds) Recent trends in diarrhoea and malnutrition. New Delhi. 1991: 64-71.

29. Savarino SJ, Fasano A, Robertson DC, Levine MM. Enteroaggregative Escherichia coli elaborate a heat-stable enterotoxin demonstrable in an in vitro rabbit intestinal model. $J$ Clin Invest 1991; 87: 1450-1455. 